\title{
Effect of Estrogen on Leptin and Expression of Leptin Receptor Transcripts in Prepubertal Dairy Heifers
}

\author{
S. R. Thorn, M. J. Meyer, M. E. Van Amburgh, and Y. R. Boisclair ${ }^{1}$ \\ Department of Animal Science, Cornell University, Ithaca, NY 14853
}

\begin{abstract}
Plasma leptin concentrations increase as growing dairy heifers approach puberty and have greater plasma estrogen. In intact and ovariectomized rodents, estrogen has been shown to modulate expression of leptin and its receptor (Ob-R). To determine if estrogen regulates the bovine leptin system, prepubertal dairy heifers were ovariectomized at $140 \mathrm{~d}$ of age or left intact. A month later, both groups received a subcutaneous injection of excipient or $17 \beta$-estradiol for 3 consecutive days. Neither ovarian status nor $17 \beta$-estradiol injection altered plasma leptin or leptin mRNA abundance in adipose tissue depots. To assess whether these factors affected $\mathrm{Ob}-\mathrm{R}$ expression, we tested 20 bovine tissues for leptin receptor (Ob-R) by using quantitative realtime PCR assays for the short receptor isoform (Ob$\mathrm{Ra})$, the long receptor isoform (Ob-Rb), and all receptor isoforms $\left(\mathrm{Ob}-\mathrm{R}_{\text {TOTAL }}\right)$. Ob- $\mathrm{R}_{\text {TOTAL }}$ was detected in all tissues, with copy numbers covering 3 orders of magnitude between the lowest and highest expressing tissues (kidney cortex vs. liver). The Ob-Rb isoform accounted for $40 \%$ of Ob- $\mathrm{R}_{\text {TOTAL }}$ in the hypothalamus, but averaged less than $3 \%$ of Ob-R $\mathrm{R}_{\text {TотAL }}$ in peripheral tissues. Reciprocally, Ob-Ra accounted for only $19 \%$ of Ob- $\mathrm{R}_{\mathrm{TOTAL}}$ in the hypothalamus and for nearly all of Ob-R $\mathrm{R}_{\text {TOTAL }}$ in most peripheral tissues. Finally, we evaluated the effects of ovarian status and $17 \beta$-estradiol on Ob-R expression in selected tissues. Treatment with $17 \beta$-estradiol reduced Ob- $\mathrm{R}_{\text {TOTAL, }} \mathrm{Ob}-\mathrm{Rb}$, and Ob-Ra expression by $70 \%$ in the uterine endometrium and tended to do the same in mammary adipose tissue. There was no effect of $17 \beta$-estradiol on Ob-R in the hypothalamus, liver, soleus muscle, or subcutaneous adipose tissue. We conclude that greater estrogen secretion does not cause increased plasma leptin in prepubertal dairy heifers but estradiol can modulate Ob-R expression in some estrogen-responsive tissues.
\end{abstract}

Received January 6, 2007.

Accepted April 19, 2007.

${ }^{1}$ Corresponding author: yrb1@cornell.edu
Key words: spatial, hypothalamus, uterus, mammary gland

\section{INTRODUCTION}

In rodents, estrogen has been shown to interact with the leptin system. Estrogen treatment decreases feed intake, BW, and adiposity, whereas ovariectomy produces the opposite effects (Mayes and Watson, 2004; Meli et al., 2004; D’Eon et al., 2005). Estrogen has also been shown to increase leptin production in ovariectomized rats (Shimizu et al., 1997; Brann et al., 1999) and in isolated adipose tissue (Casabiell et al., 1998; Kristensen et al., 1999; Machinal et al., 1999). In growing cattle, plasma leptin concentrations remain relatively constant from birth until 1 yr of age, but start to rise before the onset of puberty, at a time when plasma estrogen also increases (Evans et al., 1994a; Garcia et al., 2002; Block et al., 2003). These observations raise the possibility that gradually increasing estrogen concentrations stimulate leptin production, which then cooperates with other metabolic cues to trigger the onset of puberty in heifers.

Estrogen can also modulate leptin actions by changing leptin receptor (Ob-R) expression (Pelleymounter et al., 1999; Meli et al., 2004; Rocha et al., 2004). In rodents, alternative splicing of the single leptin receptor gene produces at least 6 mRNAs that encode a fulllength receptor $(\mathbf{O b}-\mathbf{R b})$ and a family of truncated receptors (Ob-Ra, Ob-Rc, Ob-Rd, Ob-Re, Ob-Rf; Lee et al., 1996; Myers, 2004). The truncated receptors bind leptin with normal affinity but have impaired signaling ability because they are missing most of the intracellular cytoplasmic domain (Myers, 2004). The Ob-Ra isoform is the best-characterized truncated isoform and is present at high abundance in most tissues, whereas Ob-Rb is expressed predominantly in the hypothalamus (Ghilardi et al., 1996; Fei et al., 1997; Chen et al., 1999). Two reports have suggested a dramatically different spatial expression profile in bovine tissues, with Ob-Ra expression in a limited number of tissues and ubiquitous Ob-Rb expression (Silva et al., 2002; Chelikani et al., 2003). An evaluation of estrogen effects on Ob-R expression in bovine tissues requires a quantitative as- 
sessment of the tissue distribution and expression level of Ob-Rb and Ob-Ra.

Our first objective was to test if estrogen modulated the leptin system in dairy heifers. To address this, we subjected dairy heifers to ovariectomy and estrogen administration and examined indices of leptin production (leptin mRNA in the major adipose depots and plasma leptin) and leptin receptor abundance. Our second objective was to perform a quantitative survey of Ob-Ra and $\mathrm{Ob}-\mathrm{Rb}$ expression in bovine tissues.

\section{MATERIALS AND METHODS}

\section{Animals and Experimental Design}

Sixteen prepubertal Holstein heifers were fed a complete total ration at rates needed to sustain an ADG of $650 \mathrm{~g} / \mathrm{d}$ (Meyer et al., 2006). Heifers were randomly assigned to a $2 \times 2$ factorial treatment design (Meyer et al., 2006). The first factor was ovarian status, with 8 heifers undergoing bilateral ovariectomy at approximately $140 \mathrm{~d}$ of age $(106 \mathrm{~kg}$, mean BW) and 8 heifers remaining intact. Blood samples were collected before and after ovariectomy $(\mathrm{d}-8,-6,-4,+17,+19$, and +21 , relative to surgery on $d 0$ ). The second factor was applied $30 \mathrm{~d}$ after surgery and consisted of subcutaneous injection of excipient or $17 \beta$-estradiol $(0.1 \mathrm{mg} / \mathrm{kg}$ of BW $)$ for 3 consecutive days. During the injection period, blood was collected before $(0 \mathrm{~h})$, and 24 and $48 \mathrm{~h}$ after the first injection. Plasma was prepared and assayed for leptin using a previously validated RIA (Ehrhardt et al., 2000). Heifers were killed $6 \mathrm{~h}$ after the last injection (54 h after the first injection). Tissues were collected as representative samples [subcutaneous, omental, perirenal, and mammary adipose tissue, gastrocnemius and soleus muscle, mammary parenchyma, heart, liver, lung, spleen, adrenal gland, kidney cortex, kidney medulla, small intestine (jejunum), and uterine epithelium] or in their entirety (pituitary gland, ovary, mammary lymph node, and hypothalamus). The boundaries used to dissect the hypothalamus were the rostral edge of the optic chiasm, dorsal edge of the mamillary bodies, and width of the optic chiasm. All tissues were collected within $30 \mathrm{~min}$ and immediately frozen in liquid nitrogen.

\section{RNA Isolation and Quantitative Real-Time PCR}

Tissues with significant cellular heterogeneity (hypothalamus, pituitary, and ovary) were powdered with a mortar and pestle in liquid nitrogen. Representative tissue samples (200 $\mathrm{mg}$ of adipose, $300 \mathrm{mg}$ of muscle, and $100 \mathrm{mg}$ of other tissues) were homogenized with 1 $\mathrm{mL}$ of Qiazol (Qiagen, Valencia, CA). Total RNA was isolated and purified using RNeasy Mini columns and on-column RNase-free DNase treatment (Qiagen) following the manufacturer's protocol. The quantity and integrity of RNA were determined using the BioAnalyzer and RNA Nano Lab Chip Kit (Agilent, Palo Alto, CA). Reverse transcription reactions were performed with $2 \mu \mathrm{g}$ of RNA, $500 \mathrm{ng}$ of random primers (Invitrogen, Carlsbad, CA), and ImPromII reverse transcriptase (Promega, WI) in a $20-\mu \mathrm{L}$ volume.

Real-time PCR assays were used to measure leptin, all leptin receptor isoforms $\left(\mathbf{O b}-\mathbf{R}_{\text {TOTAL }}\right)$, one of the short isoforms (Ob-Ra), and the long isoform (Ob-Rb). Each assay relies on a forward and reverse primer located in different exons and a probe spanning adjoining exons (Thorn et al., 2006). Commercially available reagents were used to detect 18S ribosomal RNA abundance (Applied Biosystems, Foster City, CA). Reactions were performed in duplicate in a $25-\mu \mathrm{L}$ volume using Perfect Real Time $2 \times$ Premix with supplied ROX dye (Takara, Madison, WI), appropriate amounts of primers and probe (Thorn et al., 2006), and diluted cDNA (10 ng of reverse-transcribed RNA for 18S, $25 \mathrm{ng}$ for leptin, and $100 \mathrm{ng}$ for Ob-R assays).

For leptin, data were expressed as relative abundance using the $\Delta \Delta C_{T}$ method (Thorn et al., 2006). For Ob-R, data were analyzed using the standard curve method. A single plasmid containing sequences homologous to the amplification products for $\mathrm{Ob}-\mathrm{R}_{\mathrm{TOTAL}}, \mathrm{Ob}-$ $\mathrm{Ra}$, and $\mathrm{Ob}-\mathrm{Rb}$ was constructed (Vandenbroucke et al., 2001). The plasmid was purified (Qiagen Plasmid Midi Prep Kit) and concentration determined spectrophotometrically. A standard curve was prepared by serial dilution of the standard plasmid (6 standards, ranging from 10 to 1,000,000 copies) and used to calculate transcript copy number for each Ob-R assay. Amplification was linear and similarly efficient for the standard plasmid in each of the $3 \mathrm{Ob}-\mathrm{R}$ assays. Transcript copy numbers were normalized to $18 \mathrm{~S}$ abundance.

\section{Statistical Analysis}

Statistical analyses were performed using the MIXED procedure of SAS (SAS Institute, Cary, NC). Mean plasma leptin concentrations in heifers before and after ovariectomy were analyzed with a model accounting for ovarian status, time, and their interaction as fixed effects, and heifer as a random effect. Plasma leptin data during the period of $17 \beta$-estradiol treatment were analyzed with a model accounting for ovarian status, estrogen treatment, their interaction, and time as a repeated measure. The Ob- $\mathrm{R}$ expression data during the period of $17 \beta$-estradiol treatment were analyzed with a model accounting for ovarian status, estrogen treatment, and their interaction. The model used for leptin mRNA abundance contained ovarian status, es- 
A

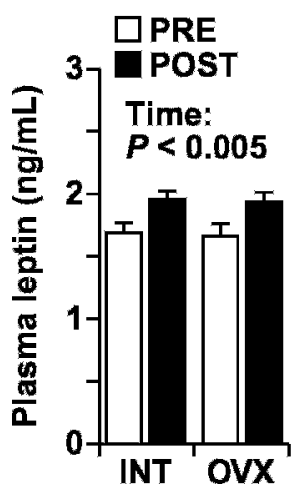

B

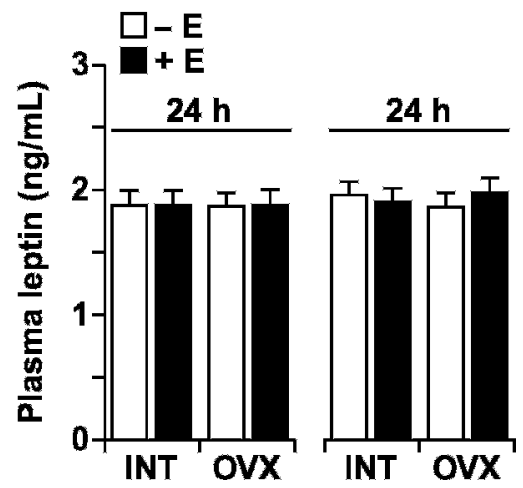

Figure 1. Effect of ovarian status and estrogen treatment on plasma leptin. A) Prepubertal heifers $(\mathrm{n}=16)$ were ovariectomized or left intact (OVX or INT) at $140 \mathrm{~d}$ of age. Blood samples were collected during the week preceding ovariectomy (PRE) and $2.5 \mathrm{wk}$ after ovariectomy (POST) and analyzed for plasma leptin. The significant effect of time is shown. B) Heifers were injected $30 \mathrm{~d}$ later with excipient or $17 \beta$-estradiol $(-\mathrm{E}$ or $+\mathrm{E})$ for 3 consecutive days. Blood samples were obtained 24 and $48 \mathrm{~h}$ after the first injection and analyzed for plasma leptin. Mean $\pm \mathrm{SE}$ is shown for each treatment.

trogen treatment, adipose depot, and their interactions as fixed effects and heifer as a random effect. Correlations and regressions were analyzed with the CORR and REG procedures. The level of statistical significance was set at $P<0.05$.

\section{RESULTS}

\section{Plasma Leptin and Adipose Tissue Leptin Expression}

Ovariectomy reduced plasma estrogen concentrations to near or below the detectable limit of $0.06 \mathrm{pg} /$ $\mathrm{mL}$ (Meyer et al., 2006). The plasma leptin concentration was similar before surgery and increased similarly over the next $3.5 \mathrm{wk}$ in both intact and ovariectomized heifers (Figure 1A). Plasma leptin remained similarly unaffected $1 \mathrm{mo}$ after surgery following estrogen treatment for 24 or $48 \mathrm{~h}$ in both intact and ovariectomized heifers (Figure 1B).

Leptin mRNA expression was greater in mammary and perirenal adipose tissue than in subcutaneous adipose tissue. The mRNA expression levels in the omental depot did not differ from the other depots (Figure 2A). Mammary leptin gene expression was positively correlated with subcutaneous, perirenal, and omental expression (Figure 2B). Neither ovarian status nor estrogen treatment affected leptin gene expression in mammary adipose tissue or the other adipose depots.

\section{A}
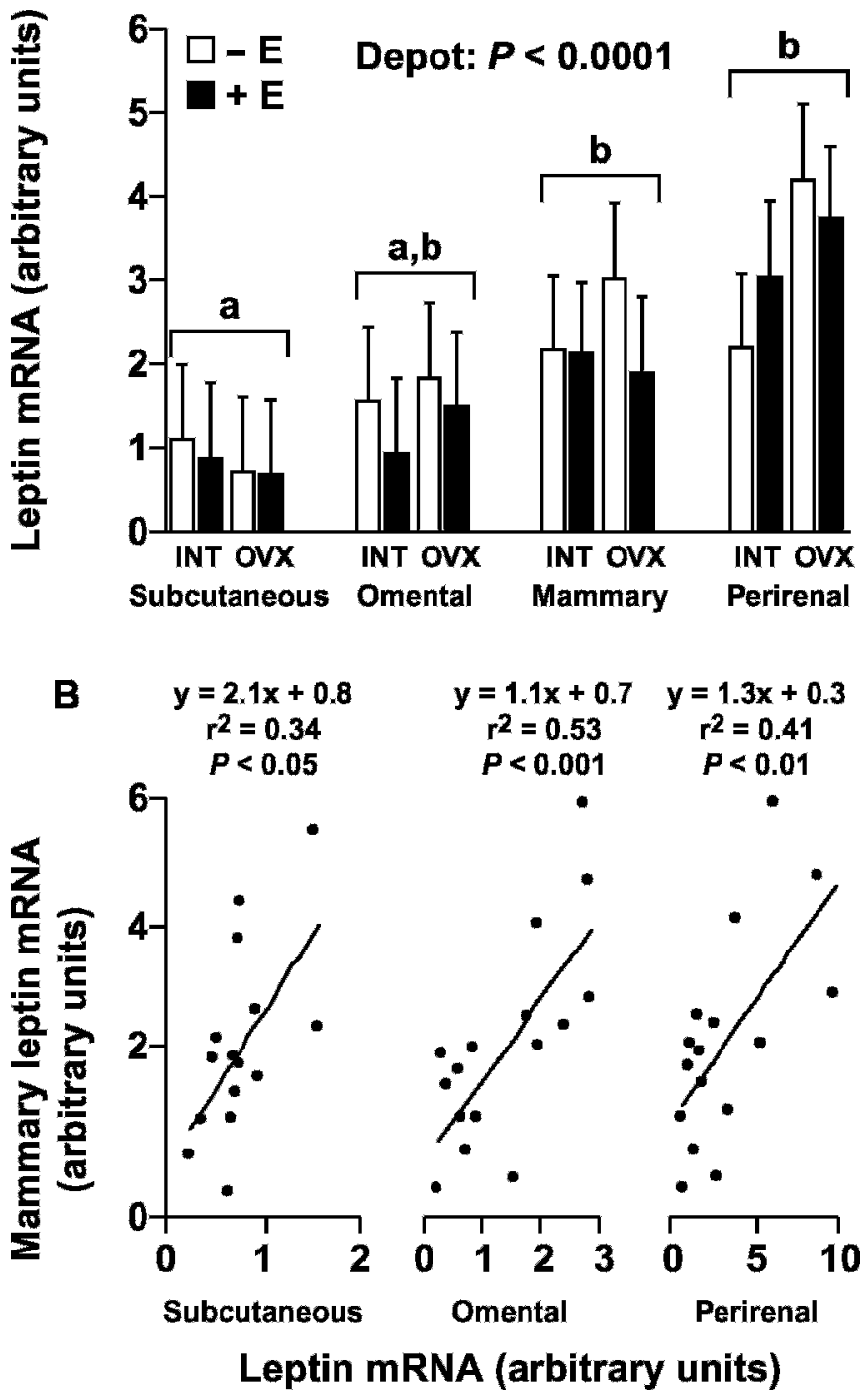

Figure 2. Effect of ovarian status and estrogen treatment on adipose tissue leptin mRNA expression. Prepubertal heifers $(n=16)$ were ovariectomized or left intact (OVX or INT) at $140 \mathrm{~d}$ of age and injected $30 \mathrm{~d}$ later with excipient or $17 \beta$-estradiol $(-\mathrm{E}$ or $+\mathrm{E})$ for 3 consecutive days. Heifers were killed and adipose tissue samples were obtained from different depots $54 \mathrm{~h}$ after first injection. Total RNA was extracted and analyzed for leptin mRNA abundance by quantitative real time PCR. A) Results are expressed as a fold difference relative to the mean expression in subcutaneous adipose tissue of excipient treated heifers (INT, $-\mathrm{E}$ ). Mean $\pm \mathrm{SE}$ is shown for each treatment within each tissue. The significant effect of adipose depot is shown and tissues with different letters differ at $P<0.05$. B) Relationship between leptin expression in mammary adipose tissue and that of the other depots.

\section{Tissue Distribution of Ob-R Expression in Prepubertal Heifers}

The Ob-R $R_{\text {TOTAL }}$ copy number covered more than 3 orders of magnitude, ranging from a low of 5 copies in 
A

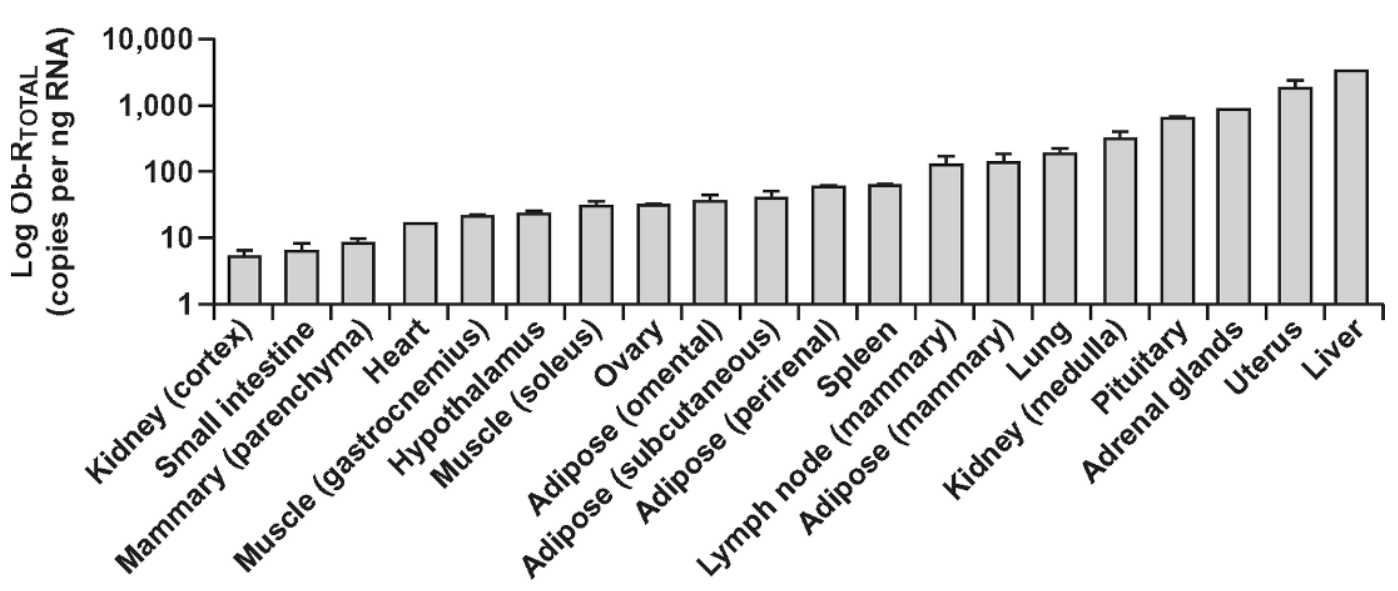

B

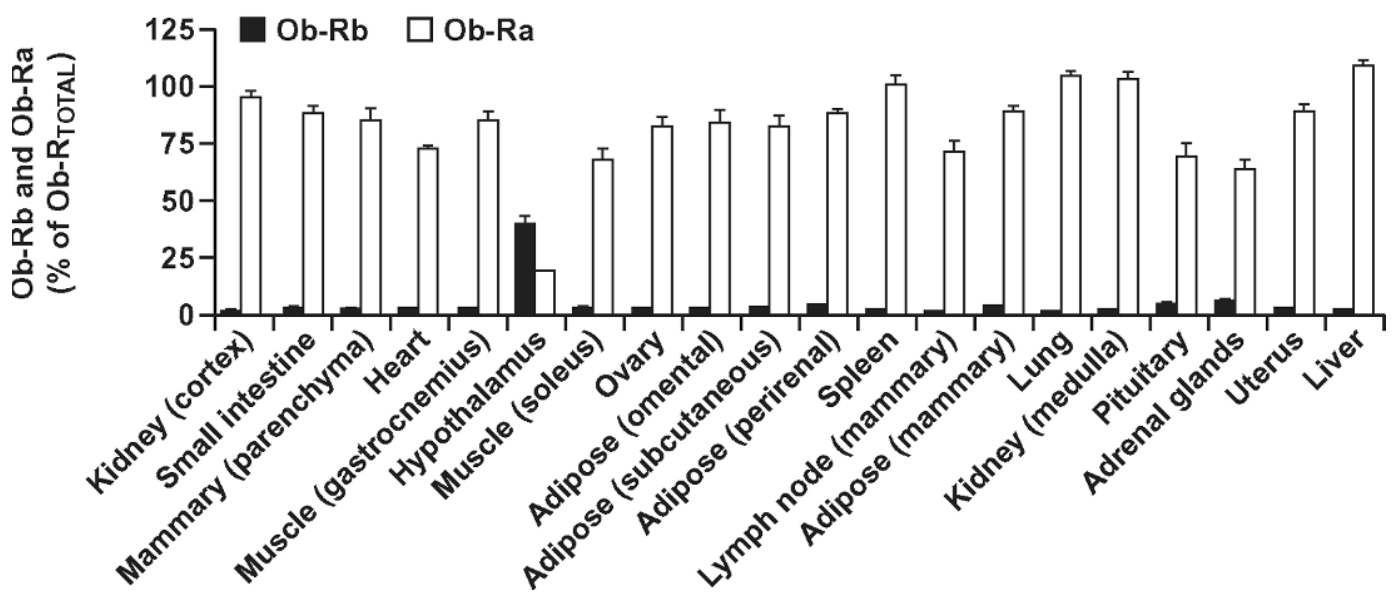

Figure 3. Expression of leptin receptor transcript isoforms across tissues in prepubertal dairy heifers. Tissues were obtained from intact excipient-treated prepubertal heifers $(\mathrm{n}=4)$ at approximately $170 \mathrm{~d}$ of age. Total RNA was isolated and transcript copy number for all leptin receptor forms $\left(\mathrm{Ob}-\mathrm{R}_{\mathrm{TO}}\right.$ тL $)$, the truncated short form $(\mathrm{Ob}-\mathrm{Ra})$, and the long form $(\mathrm{Ob}-\mathrm{Rb})$ were determined by quantitative real-time PCR. A) Ob-R RотAL abundance is expressed as transcript copy number per nanogram of input RNA. Transcript copy number is reported on a log scale to accommodate the range of expression seen across tissues. Mean \pm SE is shown for each tissue. B) Ob-Ra and Ob-Rb abundance expressed as a percentage of Ob-R $\mathrm{R}_{\mathrm{TO} \text { та }}$ expression. Mean $\pm \mathrm{SE}$ is shown for each transcript in each tissue. For Ob-Rb, the $\mathrm{SE}$ for most tissues are too small to be visible.

the kidney cortex to a high of 2,950 copies per ng of RNA in the liver (Figure $3 \mathrm{~A})$. The Ob-R $\mathrm{R}_{\text {TOTAL }}$ copy number was also high in the pituitary (630), adrenal glands (760), and uterine endometrium (1,720). The hypothalamus had fewer Ob-R $\mathrm{R}_{\text {TотAL }}$ copies than most peripheral tissues.

For each tissue, we assessed the proportion of Ob$\mathrm{R}_{\text {TOTAL }}$ accounted for by the full-length receptor (Ob$\mathrm{Rb}$ ) and the truncated Ob-Ra isoform. Ob-Rb accounted for $40 \%$ of Ob-R $\mathrm{R}_{\text {TOTAL }}$ in the hypothalamus but for $4 \%$ or less in peripheral tissues, except in the adrenal glands (6.2\%). Reciprocally, Ob-Ra represented 63 to $110 \%$ of Ob-R $\mathrm{R}_{\text {TOTAL }}$ in peripheral tissues, but less than $19 \%$ in the hypothalamus (Figure 3B). The sum of Ob-Ra and
Ob-Rb transcript copy numbers in each tissue accounted for nearly all of Ob-R $\mathrm{R}_{\text {TOTAL }}$ expression except in the hypothalamus, adrenal glands, soleus muscle, pituitary, mammary lymph node, and heart (Table 1).

\section{Estrogen Effects on Leptin Receptor Expression}

Neither ovarian status nor estrogen treatment altered Ob-R $\mathrm{R}_{\text {TOTAL }}, \mathrm{Ob}-\mathrm{Ra}$, or Ob-Rb abundance in the hypothalamus, liver, soleus muscle, and subcutaneous adipose tissue (Figure 4A and data not shown). In contrast, estrogen treatment, but not ovarian status, reduced Ob- $\mathrm{R}_{\text {TотAL }}$ in the uterine endometrium $(P<0.01$, Figure 4B). Similar effects were seen on uterine endo- 
Table 1. Proportion of all leptin receptor transcripts $\left(\mathrm{Ob}-\mathrm{R}_{\mathrm{TOTAL}}\right)$ accounted for by the sum of the short (Ob-Ra) and long $(\mathrm{Ob}-\mathrm{Rb})$ isoforms

\begin{tabular}{lcr}
\hline Tissue & $\mathrm{Ob}-\mathrm{Ra}+\mathrm{Ob}-\mathrm{Rb}^{1}$ & $\mathrm{SE}$ \\
\cline { 2 - 3 } & 59 & of Ob-R $\mathrm{TOTAL}$ \\
\cline { 2 - 3 } Hypothalamus & 70 & 5 \\
Adrenal glands & 72 & 11 \\
Muscle (soleus) & 73 & 10 \\
Pituitary & 74 & 11 \\
Lymph node (mammary) & 76 & 8 \\
Heart & 85 & 3 \\
Ovary & 87 & 8 \\
Adipose (subcutaneous) & 87 & 10 \\
Adipose (omental) & 88 & 10 \\
Mammary (parenchyma) & 89 & 11 \\
Muscle (gastrocnemius) & 89 & 7 \\
Small intestine & 92 & 6 \\
Adipose (perirenal) & 92 & 5 \\
Uterine endometrium & 93 & 6 \\
Adipose (mammary) & 98 & 4 \\
Kidney (cortex) & 103 & 4 \\
Spleen & 106 & 4 \\
Lung & 106 & 5 \\
Kidney (medulla) & 111 & 6 \\
Liver & &
\end{tabular}

${ }^{1}$ The mean sum of Ob-Ra and Ob-Rb transcipts ( $\mathrm{n}=4$ heifers).

metrial Ob-Ra and Ob-Rb expression $(P<0.05$, Figure $4 \mathrm{~B})$. Estrogen treatment also tended to reduce Ob- $\mathrm{R}_{\mathrm{TO}}$ TAL and $\mathrm{Ob}-\mathrm{Ra}$ in the mammary adipose tissue $(P<$ 0.09 , Figure 4C).

\section{DISCUSSION}

Estrogen has previously been implicated as a positive regulator of leptin production. In vitro, estrogen treatment increases leptin secretion from isolated rat adipocytes and adipose tissue explants (Kristensen et al., 1999; Machinal et al., 1999). Estrogen has also been shown to increase leptin expression in adipose tissue of humans (Casabiell et al., 1998), pigs (Qian et al., 1999), and ovariectomized rats (Shimizu et al., 1997; Brann et al., 1999). In cattle, greater plasma leptin levels in heifers approaching puberty suggest that estrogen may regulate leptin synthesis (Garcia et al., 2002; Block et al., 2003).

Prepubertal dairy heifers enable an evaluation of estrogen effects because they have low levels of plasma estrogen ranging from 2 to $6 \mathrm{pg} / \mathrm{mL}$ from as early as 2 mo of age resulting from repeating waves of nonovulatory follicular growth (Evans et al., 1994a,b). This cyclical, prepubertal estrogen production is functionally important because ovariectomy reduces mammary epithelial cell proliferation and growth in prepubertal heifers (Purup et al., 1993; Berry et al., 2003; Meyer et al., 2006). Our data indicate that intact and ovariectomized heifers have identical plasma leptin, suggesting that estrogen does not stimulate leptin production in prepu- bertal cattle. These data are unlikely to be confounded by the differences in adiposity between the intact and ovariectomized heifers because both groups weighed the same at slaughter (Meyer et al., 2006).

We also considered the possibilities that positive leptin responses required a higher plasma estrogen level or were limited to a specific adipose depot. The latter possibility was suggested by our recent observation in these heifers that estrogen induces IGF-I and progesterone receptor mRNA expression in the mammary adipose tissue, but not in subcutaneous adipose tissue (Meyer et al., 2006). Depot-specific responses to estrogen have also been found in rodents (Shimizu et al., 1997; Machinal et al., 1999). Estrogen treatment did not cause a significant change in leptin mRNA in any adipose depot, including the mammary depot. This lack of an effect of estrogen on leptin transcript abundance is consistent with our findings for plasma leptin. The possibility that estrogen increases leptin synthesis only after puberty, such as observed in the pig (Qian et al., 1999), remains to be tested in cattle.

Evidence that estrogen modulates leptin sensitivity or Ob-R expression also exists (Meli et al., 2004; Rocha et al., 2004; Clegg et al., 2006). Female sheep and rats have greater anorexic responses to central leptin administration than males (Clarke et al., 2001b; Clegg et al., 2003). In rodents, ovariectomized females have reduced hypothalamic Ob-R expression and increased appetite and these effects can be reversed with estrogen treatment (Mayes and Watson, 2004; Meli et al., 2004; D'Eon et al., 2005). Estrogen could act directly because the estrogen receptor and $\mathrm{Ob}-\mathrm{Rb}$ are co-localized in hypothalamic nuclei (Mercer et al., 1996; Diano et al., 1998; Mitra et al., 2003). Moreover, ovariectomy increased Ob-R expression in subcutaneous adipose tissue in rats and this effect was corrected by estrogen treatment (Meli et al., 2004). These observations prompted us to test the possibility that estrogen modulates $\mathrm{Ob}-\mathrm{R}$ expression in estrogen target tissues. Estrogen had no effect on Ob-R expression in the hypothalamus but did reduce Ob-R expression in the uterus. Effects of estrogen were not detected in liver, muscle, or subcutaneous adipose tissue.

The functional significance of reduced uterine Ob-R expression in estrogen-treated heifers is unknown but endometrial $\mathrm{Ob}-\mathrm{R}$ has been implicated in implantation in the mouse. The leptin receptor is expressed at implantation sites and inhibition of leptin binding with receptor antagonists reduced pregnancy rates and the number of implantation sites (Ramos et al., 2005; Yoon et al., 2005). This function may explain why leptin treatment of the $o b / o b$ mouse failed to restore pregnancy unless the treatment was extended beyond the time of implantation (Chehab et al., 1997; Mounzih et al., 1997; 
A

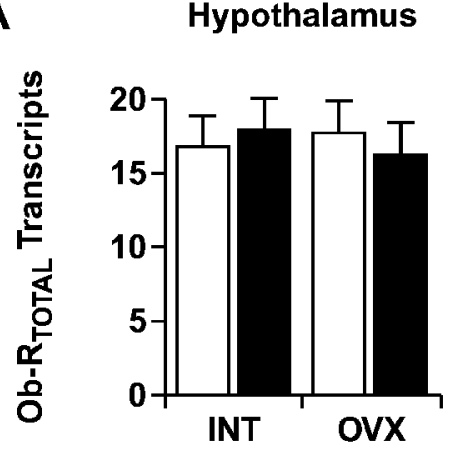

Liver

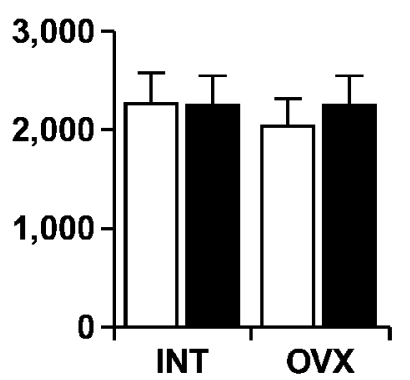

Muscle

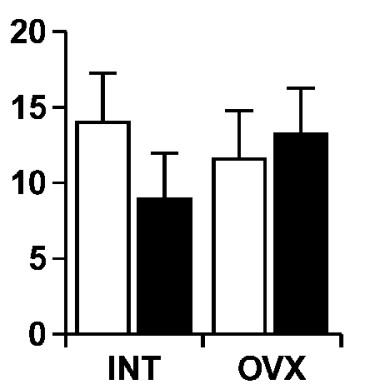

Adipose

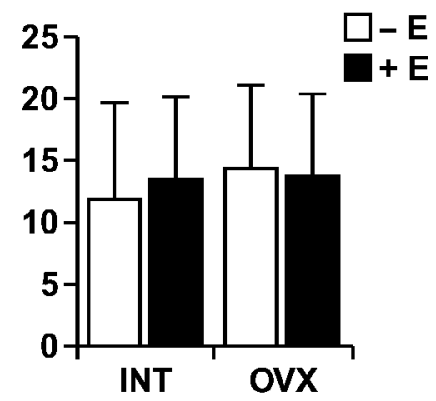

B Uterine endometrium
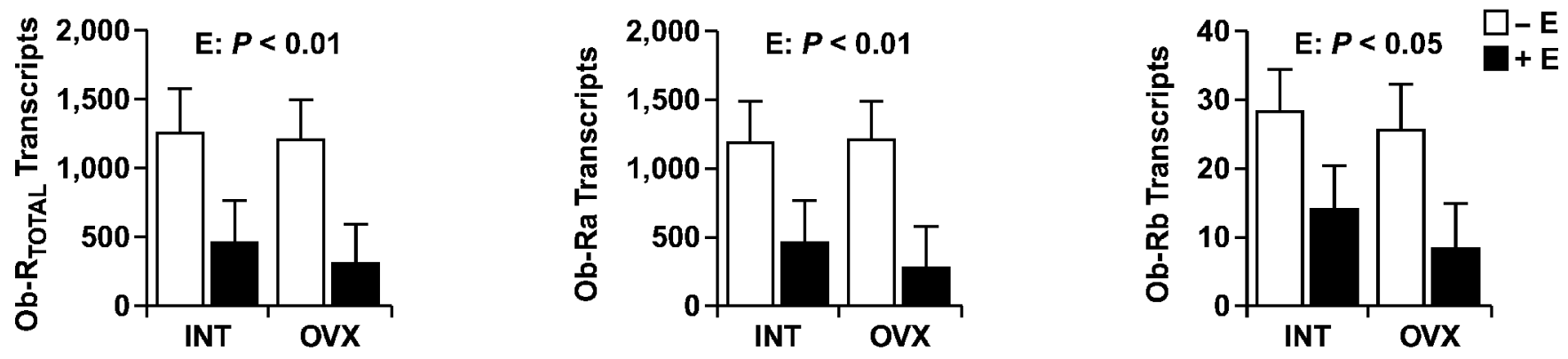

C

Mammary adipose tissue
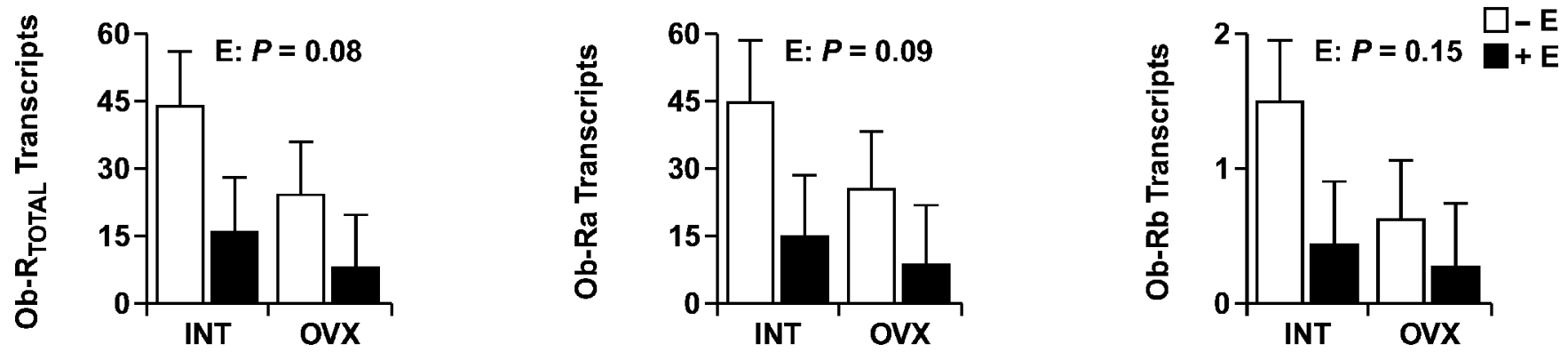

Figure 4. Effect of ovarian status and estrogen treatment on leptin receptor expression. Prepubertal heifers $(\mathrm{n}=16)$ were ovariectomized or left intact (OVX or INT) at $140 \mathrm{~d}$ of age and injected $30 \mathrm{~d}$ later with excipient or $17 \beta$-estradiol (-E, open bars or $+\mathrm{E}$, closed bars) for 3 consecutive days. Heifers were killed and tissue samples were obtained $54 \mathrm{~h}$ after first injection. Total RNA was isolated and transcript copy number for all leptin receptor forms $\left(\mathrm{Ob}-\mathrm{R}_{\mathrm{TOTAL}}\right)$, the truncated short form $(\mathrm{Ob}-\mathrm{Ra})$, and the long form $(\mathrm{Ob}-\mathrm{Rb})$ were determined by quantitative real time PCR. A) Ob- $\mathrm{R}_{\mathrm{TOTAL}}$ abundance in hypothalamus, liver, soleus muscle, and subcutaneous adipose expressed as transcript copy number per nanogram of input RNA. B) Ob- $\mathrm{R}_{\mathrm{TOTAL}}, \mathrm{Ob}-\mathrm{Ra}$, and $\mathrm{Ob}-\mathrm{Rb}$ abundance in uterine endometrium; and $\mathrm{C}$ ) mammary adipose tissue. Mean $\pm \mathrm{SE}$ is shown for each treatment within each tissue. The significant effect of estrogen (E) is given.

Malik et al., 2001). Given these observations, it would be of interest to measure Ob-R abundance in the bovine uterine endometrium through the estrous cycle and during implantation.

In rodents, leptin has been shown to act on the hypothalamus and other regions of the central nervous system to regulate feeding and $\mathrm{BW}$ but leptin has few direct peripheral target tissues (Ahima and Flier, 2000; Myers, 2004). Compelling evidence also exists for central actions of leptin in ruminants (Clarke et al., 2001a;
Williams et al., 2002; Boisclair et al., 2006), but whether leptin also acts on peripheral tissues has been the subject of controversy (Silva et al., 2002; Chelikani et al., 2003; Lulu Strat et al., 2005). We found that leptin receptor expression $\left(\mathrm{Ob}-\mathrm{R}_{\mathrm{TOTAL}}\right)$ was greater in most peripheral tissues than in the hypothalamus, and was greatest in liver, a tissue where the leptin receptor is completely dispensable in the mouse (Cohen et al., 2001; de Luca et al., 2005). In the case of leptin, however, total receptor abundance $\left(\mathrm{Ob}-\mathrm{R}_{\text {TOTAL }}\right)$ does not 
provide an accurate index of leptin responsiveness. This is because the primary leptin receptor transcript is spliced into mRNAs encoding the fully functional leptin receptor $(\mathrm{Ob}-\mathrm{Rb})$ or a family of truncated isoforms with impaired signaling ability (Ob-Ra, Ob-Rc, Ob-Rd, ObRf; Lee et al., 1996; Myers, 2004).

To clarify this issue, we determined the fraction of $\mathrm{Ob}-\mathrm{R}_{\text {TOTAL }}$ transcripts accounted for by $\mathrm{Ob}-\mathrm{Rb}$ and $\mathrm{Ob}-$ $\mathrm{Ra}$, the later being the most frequently occurring truncated receptor present in the mouse (Ghilardi et al., 1996). We found that Ob-Rb mRNA accounted for the majority of Ob-R transcripts in the hypothalamus but for less than $3 \%$ on average in peripheral tissues. In contrast, Ob-Ra expression was ubiquitous and accounted for nearly all Ob- $\mathrm{R}_{\text {TOTAL }}$ in most peripheral tissues. Our findings are in complete agreement with results obtained in other species (Ghilardi et al., 1996; Fei et al., 1997; Chen et al., 1999), but disagree with 2 recent surveys performed in cattle using nonquantitative reverse transcription-PCR (Silva et al., 2002; Chelikani et al., 2003). These authors reported Ob-Ra expression in only 5 of 27 tissues surveyed. In both studies, however, the forward Ob-Ra primer contained a mismatch with the bovine Ob-R sequence, likely leading to inefficient amplification (Silva et al., 2002; Chelikani et al., 2003). They also reported ubiquitous expression of Ob-Rb, which we now show to account for a very small proportion of Ob- $\mathrm{R}_{\text {TотАL }}$ in peripheral tissues. We did not attempt to quantify the abundance of the other truncated Ob-R isoforms because they have yet to be described in cattle. If these exist, however, our data indicate that they would account for a small proportion of the total receptor transcripts in bovine tissues, with the possible exception of the hypothalamus, pituitary, adrenal, heart, mammary lymph node, and soleus muscle.

Our data on the relative abundance of $\mathrm{Ob}-\mathrm{Rb}$ and Ob-Ra have important implications for the sites of leptin action in cattle. Because Ob-Rb is the only isoform capable of activating all known transduction pathways in vivo attributed to leptin (Bates et al., 2003; Myers, 2004), our data indicate that the hypothalamus is the major site of leptin action in cattle as is the case in rodents (Ahima and Flier, 2000; Myers, 2004). Indeed, the obese and diabetic phenotype of mice suffering from leptin signaling deficiencies is completely abolished by correcting the genetic defect only in the hypothalamus (Coppari et al., 2005; de Luca et al., 2005). The $d b / d b$ mice, which lack Ob-Rb but retain normal expression of Ob-Ra, are phenotypically indistinguishable from the leptin-deficient $o b / o b$ mice (Chen et al., 1996; Ahima and Flier, 2000; Myers, 2004). Moreover, knockout of the leptin receptor only in neural tissues phenocopies the $d b / d b$ mouse (Cohen et al., 2001; Balthasar et al.,
2004; McMinn et al., 2005). Reciprocally, dominance of the truncated Ob-Ra receptor in nonhypothalamic tissues suggests that direct leptin actions in peripheral tissues are subtle. Some have suggested that the predominant role of $\mathrm{Ob}-\mathrm{Ra}$ is to limit action, either by sequestering leptin away from $\mathrm{Ob}-\mathrm{Rb}$ or by serving as a source of leptin binding protein in circulation (Cohen et al., 2005; Gallardo et al., 2005).

In summary, our data show that estrogen regulates leptin receptor abundance in some estrogen-responsive tissues but has no effect on leptin production. The majority of leptin receptor transcripts are accounted for by $\mathrm{Ob}-\mathrm{Rb}$ in the hypothalamus and by Ob-Ra in peripheral tissues. This receptor distribution agrees with the prevailing model of leptin action wherein most of its actions are initiated in the hypothalamus.

\section{ACKNOWLEDGMENTS}

The authors thank Richard Ehrhardt, Jin Wook Kim, and Iori Ueki for assistance with tissue collection, Ramona Ehrhardt for assistance with leptin RIA, and Patricia Johnson for use of the real-time PCR instrumentation. This project was supported by the National Research Initiative Competitive Grant 2003-35203-12832 from the USDA Cooperative State Research, Education, and Extension Service and by the Center for Advanced Technology in Biotechnology (which is supported by the New York State Science and Technology Foundation and its industrial partners).

\section{REFERENCES}

Ahima, R. S., and J. S. Flier. 2000. Leptin. Annu. Rev. Physiol. 62:413-437.

Balthasar, N., R. Coppari, J. McMinn, S. M. Liu, C. E. Lee, V. Tang, C. D. Kenny, R. A. McGovern, S. C. Chua, Jr., J. K. Elmquist, and B. B. Lowell. 2004. Leptin receptor signaling in POMC neurons is required for normal body weight homeostasis. Neuron 42:983991.

Bates, S. H., W. H. Stearns, T. A. Dundon, M. Schubert, A. W. Tso, Y. Wang, A. S. Banks, H. J. Lavery, A. K. Haq, E. Maratos-Flier, B. G. Neel, M. W. Schwartz, and M. G. Myers, Jr. 2003. STAT3 signalling is required for leptin regulation of energy balance but not reproduction. Nature 421:856-859.

Berry, S. D., P. M. Jobst, S. E. Ellis, R. D. Howard, A. V. Capuco, and R. M. Akers. 2003. Mammary epithelial proliferation and estrogen receptor alpha expression in prepubertal heifers: Effects of ovariectomy and growth hormone. J. Dairy Sci. 86:2098-2105.

Block, S. S., J. M. Smith, R. A. Ehrhardt, M. C. Diaz, R. P. Rhoads, M. E. Van Amburgh, and Y. R. Boisclair. 2003. Nutritional and developmental regulation of plasma leptin in dairy cattle. J. Dairy Sci. 86:3206-3214.

Boisclair, Y. R., S. R. Wesolowski, J. W. Kim, and R. A. Ehrhardt. 2006. Roles of growth hormone and leptin in the periparturient dairy cow. Pages 327-346 in Ruminant Physiology: Digestion, metabolism, and impact of nutrition on gene expression, immunology, and stress. K. Sejrsen, T. Hvelplund, and M. O. Nielsen, ed. Wageningen Academic Publishers, Wageningen, the Netherlands. 
Brann, D. W., L. De Sevilla, P. L. Zamorano, and V. B. Mahesh. 1999. Regulation of leptin gene expression and secretion by steroid hormones. Steroids 64:659-663.

Casabiell, X., V. Pineiro, R. Peino, M. Lage, J. Camina, R. Gallego, L. G. Vallejo, C. Dieguez, and F. F. Casanueva. 1998. Gender differences in both spontaneous and stimulated leptin secretion by human omental adipose tissue in vitro: Dexamethasone and estradiol stimulate leptin release in women, but not in men. J. Clin. Endocrinol. Metab. 83:2149-2155.

Chehab, F. F., K. Mounzih, R. Lu, and M. E. Lim. 1997. Early onset of reproductive function in normal female mice treated with leptin. Science 275:88-90.

Chelikani, P. K., D. R. Glimm, and J. J. Kennelly. 2003. Short communication: Tissue distribution of leptin and leptin receptor mRNA in the bovine. J. Dairy Sci. 86:2369-2372.

Chen, H., O. Charlat, L. A. Tartaglia, E. A. Woolf, X. Weng, S. J. Ellis, N. D. Lakey, J. Culpepper, K. J. Moore, R. E. Breitbart, G. M. Duyk, R. I. Tepper, and J. P. Morgenstern. 1996. Evidence that the diabetes gene encodes the leptin receptor: Identification of a mutation in the leptin receptor gene in $\mathrm{db} / \mathrm{db}$ mice. Cell 84:491-495.

Chen, S. C., J. P. Kochan, L. A. Campfield, P. Burn, and R. J. Smeyne. 1999. Splice variants of the OB receptor gene are differentially expressed in brain and peripheral tissues of mice. J. Recept. Signal Transduct. Res. 19:245-266.

Clarke, I. J., B. Henry, J. Iqbal, and J. W. Goding. 2001a. Leptin and the regulation of food intake and the neuroendocrine axis in sheep. Clin. Exp. Pharmacol. Physiol. 28:106-107.

Clarke, I. J., A. J. Tilbrook, A. I. Turner, B. W. Doughton, and J. W. Goding. 2001b. Sex, fat and the tilt of the earth: Effects of sex and season on the feeding response to centrally administered leptin in sheep. Endocrinology 142:2725-2728.

Clegg, D. J., L. M. Brown, S. C. Woods, and S. C. Benoit. 2006. Gonadal hormones determine sensitivity to central leptin and insulin. Diabetes 55:978-987.

Clegg, D. J., C. A. Riedy, K. A. Smith, S. C. Benoit, and S. C. Woods 2003. Differential sensitivity to central leptin and insulin in male and female rats. Diabetes 52:682-687.

Cohen, P., G. Yang, X. Yu, A. A. Soukas, C. S. Wolfish, J. M. Friedman, and C. Li. 2005. Induction of leptin receptor expression in the liver by leptin and food deprivation. J. Biol. Chem. 280:10034-10039.

Cohen, P., C. Zhao, X. Cai, J. M. Montez, S. C. Rohani, P. Feinstein, P. Mombaerts, and J. M. Friedman. 2001. Selective deletion of leptin receptor in neurons leads to obesity. J. Clin. Invest. 108:1113-1121.

Coppari, R., M. Ichinose, C. E. Lee, A. E. Pullen, C. D. Kenny, R. A. McGovern, V. Tang, S. M. Liu, T. Ludwig, S. C. Chua, Jr., B. B. Lowell, and J. K. Elmquist. 2005. The hypothalamic arcuate nucleus: A key site for mediating leptin's effects on glucose homeostasis and locomotor activity. Cell Metab. 1:63-72.

de Luca, C., T. J. Kowalski, Y. Zhang, J. K. Elmquist, C. Lee, M. W. Kilimann, T. Ludwig, S. M. Liu, and S. C. Chua, Jr. 2005. Complete rescue of obesity, diabetes, and infertility in $\mathrm{db} / \mathrm{db}$ mice by neuron-specific LEPR-B transgenes. J. Clin. Invest. 115:34843493.

D'Eon, T. M., S. C. Souza, M. Aronovitz, M. S. Obin, S. K. Fried, and A. S. Greenberg. 2005. Estrogen regulation of adiposity and fuel partitioning. Evidence of genomic and non-genomic regulation of lipogenic and oxidative pathways. J. Biol. Chem. 280:3598335991.

Diano, S., S. P. Kalra, H. Sakamoto, and T. L. Horvath. 1998. Leptin receptors in estrogen receptor-containing neurons of the female rat hypothalamus. Brain Res. 812:256-259.

Ehrhardt, R. A., R. M. Slepetis, J. Siegal-Willott, M. E. Van Amburgh, A. W. Bell, and Y. R. Boisclair. 2000. Development of a specific radioimmunoassay to measure physiological changes of circulating leptin in cattle and sheep. J. Endocrinol. 166:519-528.

Evans, A. C., G. P. Adams, and N. C. Rawlings. 1994a. Endocrine and ovarian follicular changes leading up to the first ovulation in prepubertal heifers. J. Reprod. Fertil. 100:187-194.
Evans, A. C., G. P. Adams, and N. C. Rawlings. 1994b. Follicular and hormonal development in prepubertal heifers from 2 to 36 weeks of age. J. Reprod. Fertil. 102:463-470.

Fei, H., H. J. Okano, C. Li, G. H. Lee, C. Zhao, R. Darnell, and J. M. Friedman. 1997. Anatomic localization of alternatively spliced leptin receptors $(\mathrm{Ob}-\mathrm{R})$ in mouse brain and other tissues. Proc. Natl. Acad. Sci. USA 94:7001-7005.

Gallardo, N., C. Arribas, M. Villar, M. Ros, J. M. Carrascosa, C. Martinez, and A. Andres. 2005. ObRa and ObRe are differentially expressed in adipose tissue in aged food-restricted rats: Effects on circulating soluble leptin receptor levels. Endocrinology 146:4934-4942.

Garcia, M. R., M. Amstalden, S. W. Williams, R. L. Stanko, C. D. Morrison, D. H. Keisler, S. E. Nizielski, and G. L. Williams. 2002. Serum leptin and its adipose gene expression during pubertal development, the estrous cycle, and different seasons in cattle. J. Anim. Sci. 80:2158-2167.

Ghilardi, N., S. Ziegler, A. Wiestner, R. Stoffel, M. H. Heim, and R. C. Skoda. 1996. Defective STAT signaling by the leptin receptor in diabetic mice. Proc. Natl. Acad. Sci. USA 93:6231-6235.

Kristensen, K., S. B. Pedersen, and B. Richelsen. 1999. Regulation of leptin by steroid hormones in rat adipose tissue. Biochem. Biophys. Res. Commun. 259:624-630.

Lee, G. H., R. Proenca, J. M. Montez, K. M. Carroll, J. G. Darvishzadeh, J. I. Lee, and J. M. Friedman. 1996. Abnormal splicing of the leptin receptor in diabetic mice. Nature 379:632-635.

Lulu Strat, A., T. A. Kokta, M. V. Dodson, A. Gertler, Z. Wu, and R. A. Hill. 2005. Early signaling interactions between the insulin and leptin pathways in bovine myogenic cells. Biochim. Biophys. Acta 1744:164-175.

Machinal, F., M. N. Dieudonne, M. C. Leneveu, R. Pecquery, and Y. Giudicelli. 1999. In vivo and in vitro ob gene expression and leptin secretion in rat adipocytes: Evidence for a regional specific regulation by sex steroid hormones. Endocrinology 140:15671574.

Malik, N. M., N. D. Carter, J. F. Murray, R. J. Scaramuzzi, C. A Wilson, and M. J. Stock. 2001. Leptin requirement for conception, implantation, and gestation in the mouse. Endocrinology 142:5198-5202.

Mayes, J. S., and G. H. Watson. 2004. Direct effects of sex steroid hormones on adipose tissues and obesity. Obes. Rev. 5:197-216.

McMinn, J. E., S. M. Liu, H. Liu, I. Dragatsis, P. Dietrich, T. Ludwig, C. N. Boozer, and S. C. Chua, Jr. 2005. Neuronal deletion of Lepr elicits diabesity in mice without affecting cold tolerance or fertility. Am. J. Physiol. Endocrinol. Metab. 289:E403-E411.

Meli, R., M. Pacilio, G. M. Raso, E. Esposito, A. Coppola, A. Nasti, C. Di Carlo, C. Nappi, and R. Di Carlo. 2004. Estrogen and raloxifene modulate leptin and its receptor in hypothalamus and adipose tissue from ovariectomized rats. Endocrinology 145:3115-3121.

Mercer, J. G., N. Hoggard, L. M. Williams, C. B. Lawrence, L. T. Hannah, and P. Trayhurn. 1996. Localization of leptin receptor mRNA and the long form splice variant $(\mathrm{Ob}-\mathrm{Rb})$ in mouse hypothalamus and adjacent brain regions by in situ hybridization. FEBS Lett. 387:113-116.

Meyer, M. J., A. V. Capuco, Y. R. Boisclair, and M. E. Van Amburgh. 2006. Estrogen-dependent responses of the mammary fat pad in prepubertal dairy heifers. J. Endocrinol. 190:819-827.

Mitra, S. W., E. Hoskin, J. Yudkovitz, L. Pear, H. A. Wilkinson, S. Hayashi, D. W. Pfaff, S. Ogawa, S. P. Rohrer, J. M. Schaeffer, B. S. McEwen, and S. E. Alves. 2003. Immunolocalization of estrogen receptor beta in the mouse brain: Comparison with estrogen receptor alpha. Endocrinology 144:2055-2067.

Mounzih, K., R. Lu, and F. F. Chehab. 1997. Leptin treatment rescues the sterility of genetically obese $o b / o b$ males. Endocrinology 138:1190-1193.

Myers, M. G., Jr. 2004. Leptin receptor signaling and the regulation of mammalian physiology. Recent Prog. Horm. Res. 59:287-304.

Pelleymounter, M. A., M. B. Baker, and M. McCaleb. 1999. Does estradiol mediate leptin's effects on adiposity and body weight? Am. J. Physiol. 276:E955-E963.

Purup, S., K. Sejrsen, J. Foldager, and R. M. Akers. 1993. Effect of exogenous bovine growth hormone and ovariectomy on prepuber- 
tal mammary growth, serum hormones and acute in-vitro proliferative response of mammary explants from Holstein heifers. J. Endocrinol. 139:19-26.

Qian, H., C. R. Barb, M. M. Compton, G. J. Hausman, M. J. Azain, R. R. Kraeling, and C. A. Baile. 1999. Leptin mRNA expression and serum leptin concentrations as influenced by age, weight, and estradiol in pigs. Domest. Anim. Endocrinol. 16:135-143.

Ramos, M. P., B. R. Rueda, P. C. Leavis, and R. R. Gonzalez. 2005. Leptin serves as an upstream activator of an obligatory signaling cascade in the embryo-implantation process. Endocrinology 146:694-701.

Rocha, M., C. Bing, G. Williams, and M. Puerta. 2004. Physiologic estradiol levels enhance hypothalamic expression of the long form of the leptin receptor in intact rats. J. Nutr. Biochem. 15:328-334.

Shimizu, H., Y. Shimomura, Y. Nakanishi, T. Futawatari, K. Ohtani, N. Sato, and M. Mori. 1997. Estrogen increases in vivo leptin production in rats and human subjects. J. Endocrinol 154:285-292.
Silva, L. F., M. J. VandeHaar, M. S. Weber Nielsen, and G. W. Smith. 2002. Evidence for a local effect of leptin in bovine mammary gland. J. Dairy Sci. 85:3277-3286.

Thorn, S. R., S. Purup, W. S. Cohick, M. Vestergaard, K. Sejrsen, and Y.R. Boisclair. 2006. Leptin does not act directly on mammary epithelial cells in prepubertal dairy heifers. J. Dairy Sci. 89:1467-1477.

Vandenbroucke, I. I., J. Vandesompele, A. D. Paepe, and L. Messiaen. 2001. Quantification of splice variants using real-time PCR. Nucleic Acids Res. 29:e68. doi:10.1093/nar/29.13.e68

Williams, G. L., M. Amstalden, M. R. Garcia, R. L. Stanko, S. E. Nizielski, C. D. Morrison, and D. H. Keisler. 2002. Leptin and its role in the central regulation of reproduction in cattle. Domest. Anim. Endocrinol. 23:339-349.

Yoon, S. J., K. Y. Cha, and K. A. Lee. 2005. Leptin receptors are down-regulated in uterine implantation sites compared to interimplantation sites. Mol. Cell. Endocrinol. 232:27-35. 